\title{
Covid-19 and the Transport System
}

\author{
* \\ Hermann Knoflacher ${ }^{1}$ \\ ORCID: 0000-0002-5103-6455
}

\begin{abstract}
The fascinating thing about the 'finding that the measures taken to contain this pandemic in the transport system have, on the one hand, achieved in a very short time precisely those effects that qualified transport scientists have been demanding from politicians for decades and, on the other hand, the fact that it has not been possible to realize the same successes in the transport system without C19, although human lives, hygiene and health are at stake in both areas. Unfortunately, little is known about the origin of C19. In the Corona crisis, one also recognizes the importance of certain self-sufficiency, not only for medical care and equipment. The relationship between C19 and the transport system is closer than one would think. C19 is the result of the thoughtless intrusion of humans into nature, which was no longer respected in its intrinsic value, but devalued to the object of marketing. The most effective measure against car addiction is to prevent the "docking" of the car to the home and all other places of human activity. This measure has been shown to be most effective in combating viral infections. The measures to be taken are; 1. car-free settlements and sanctions, 2. speed limits and effective control, 3. technical measures to minimise the risks of the remaining car traffic.
\end{abstract}

Keywords: Pandemic, C19, transport system. 


\section{Introduction}

The fascinating thing about the 'finding that the measures taken to contain this pandemic in the transport system have, on the one hand, achieved in a very short time precisely those effects that qualified transport scientists have been demanding from politicians for decades and, on the other hand, the fact that it has not been possible to realize the same successes in the transport system without $\mathrm{C} 19$, although human lives, hygiene and health are at stake in both areas. The topic cannot be dealt with exhaustively in this short contribution. It is limited to the essential differences and interrelationships. The fact that $\mathrm{C} 19$ suddenly made the interrelation between and the transport system visible from an unusual side would be an advantage if intelligent conclusions were drawn from it.

Since viruses can only multiply in suitable host cells in order to spread extracellularly as virions (Merriam-Webster Dictionary,2021), they depend on suitable transport systems. The speed of spread therefore depends on the properties of these means of transport, the transport chain, the switching possibilities, the connectivity, whether these accommodate the spread and thus the desired multiplication, quantitative growth or act as barriers. It is the same principle that is applied in the human-driven economic system of neoliberalism, which, however, forcibly removes borders based on the demand for limitless growth. However, it is not called a pandemic there, but globalization to give it a positive connotation. Here, however, I want to limit myself to the transport system for passenger traffic and specifically to the effects of the car. This too has no energy of its own but can influence that of its owner and society in such a way that it provides for it and much more.

\section{The long road to a fast trip around the world}

Unfortunately, little is known about the origin of C19. What is known is its family, whose root is several billion years old and has apparently been able to successfully cope with all changes in environmental conditions up to now. In order to reach humans, it has probably already overcome several barriers. As far as is known today, the last part of the transport chain ran from the bats via an intermediate host and the wild animal market in Wuhan to the human(s). In doing so, it used its advantage of incubation time (Healthline, 2021), which for $\mathrm{C} 19$ is 2 to 14 days. This is about twice as long as for SARS1. This also became conspicuous in China in 2002 and had global effects (Wikipedia, 2021a). 


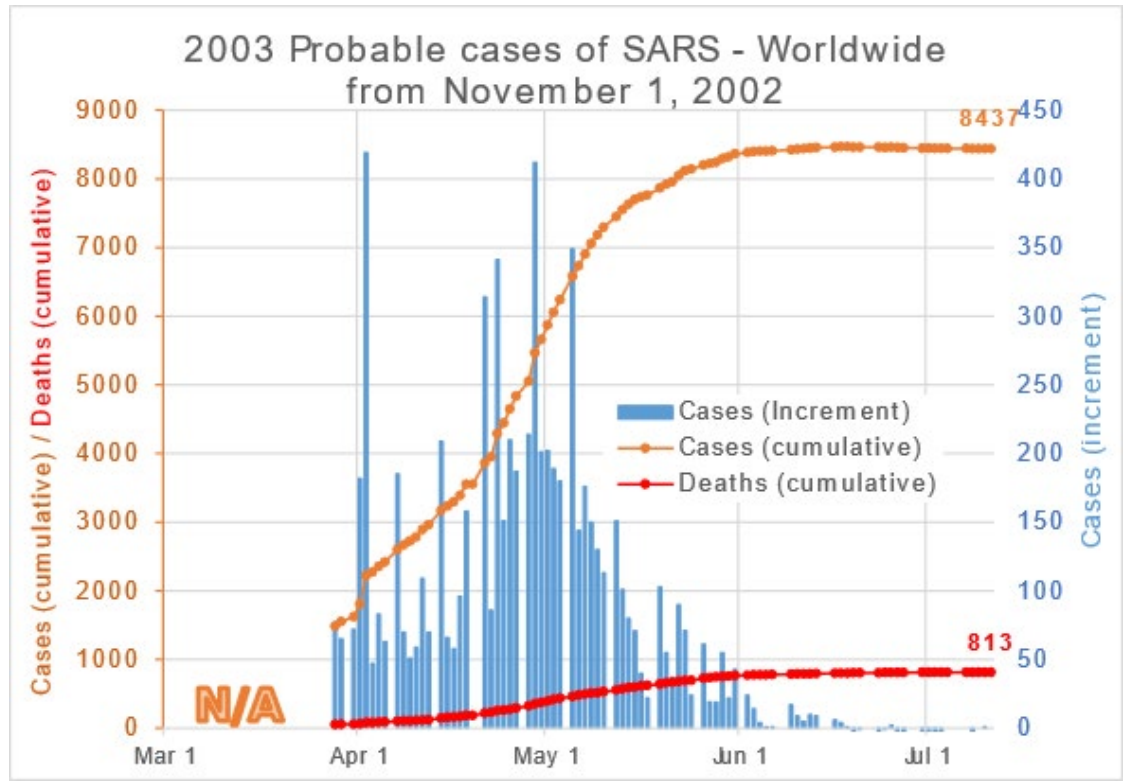

The number of infections, assuming an exponential increase in the number of cases, increases more than a thousandfold just because of the longer incubation period, until it reaches the same conspicuousness. This development continues until the countermeasures take full effect.

\section{Better propagation conditions today}

Since 2000, the world has changed: the population has increased from 6.14 billion to 7.8 billion, China's gross national product has more than doubled in the last 20 years and so have its foreign relations (Wikipedia, 2021b). The number of aircraft operated by Air China alone has more than quadrupled since 2000, and more international airlines have been added. China is also striving to catch up particularly fast in the mainstream with its rising GNP in motorization. 


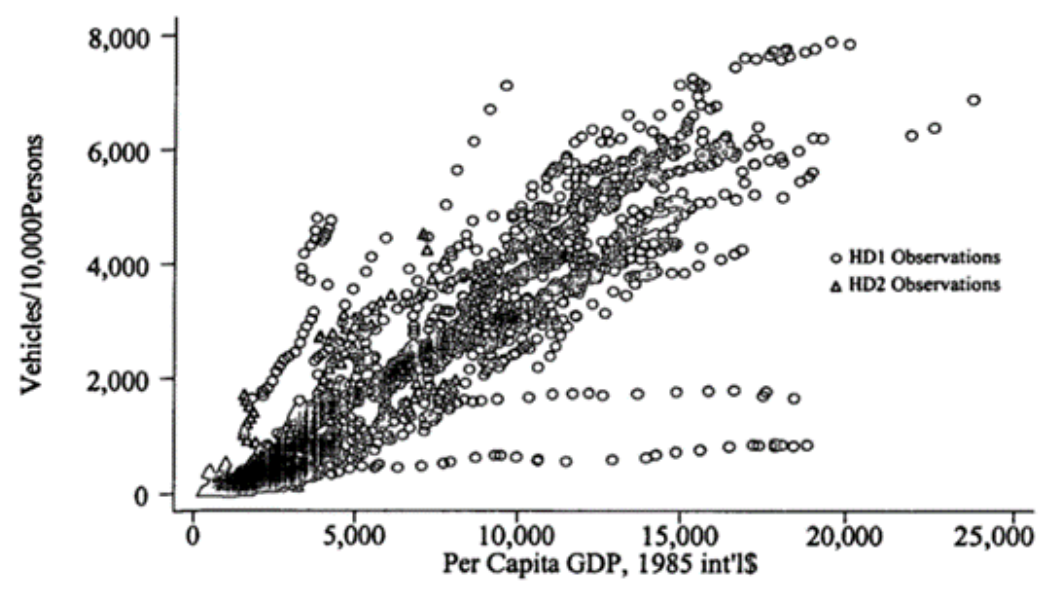

\section{Ideal conditions for the spread of C19.}

The times when it took 80 days to circumnavigate the globe, as in Jules Verne's 1873 (Wikipedi, 2021c) adventure novel, are long gone. C19 can circumnavigate the globe dozens of times within its incubation period, encountering many millions of people, its new potential hosts, before it is discovered. What was thought to be a Chinese problem in the rest of the world was suddenly there almost everywhere thanks to fast technical means of transport. Also, the high density of passengers in the enclosed space meant that $\mathrm{C} 19$ was already able to use the journey perfectly for spreading from the airports by public transport and even more so by car traffic. The Spanish flu of 1918/19 (Wikipedia, 2021d) already used the transport system of that time, but also the consequences of the First World War, for its global impact. Since then, the time of the steamships, the transport system has accelerated enormously through air traffic and motorization, and travel distances have increased exponentially. 


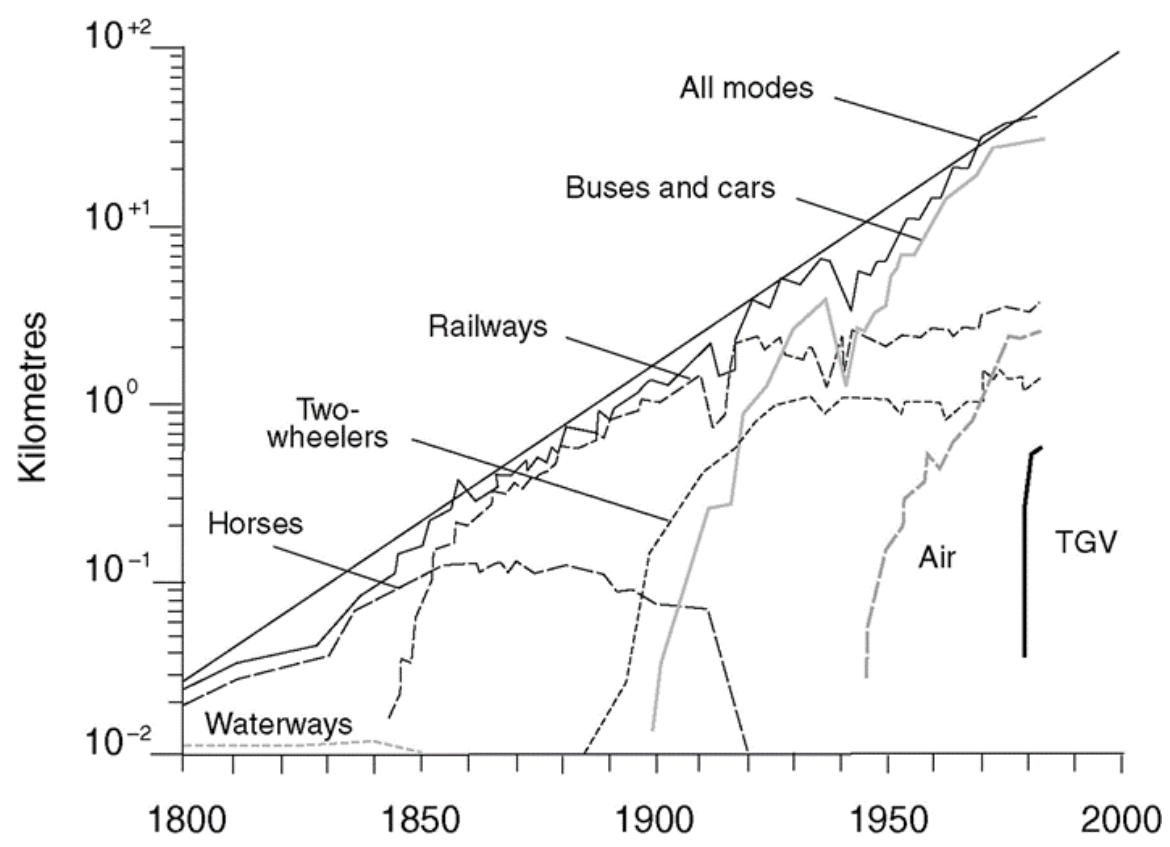

If the speed in space increases, this does not lead to a shortening of travel times, as traditional transport science assumes, but to an increase in the length of journeys (Knoflacher, 1985). Especially with the car, the reachable area thus expands with the square of the speed, while with public transport - mostly again under good conditions of infection - it works through the stops and stations. Added to this is the exponentially increasing population. 


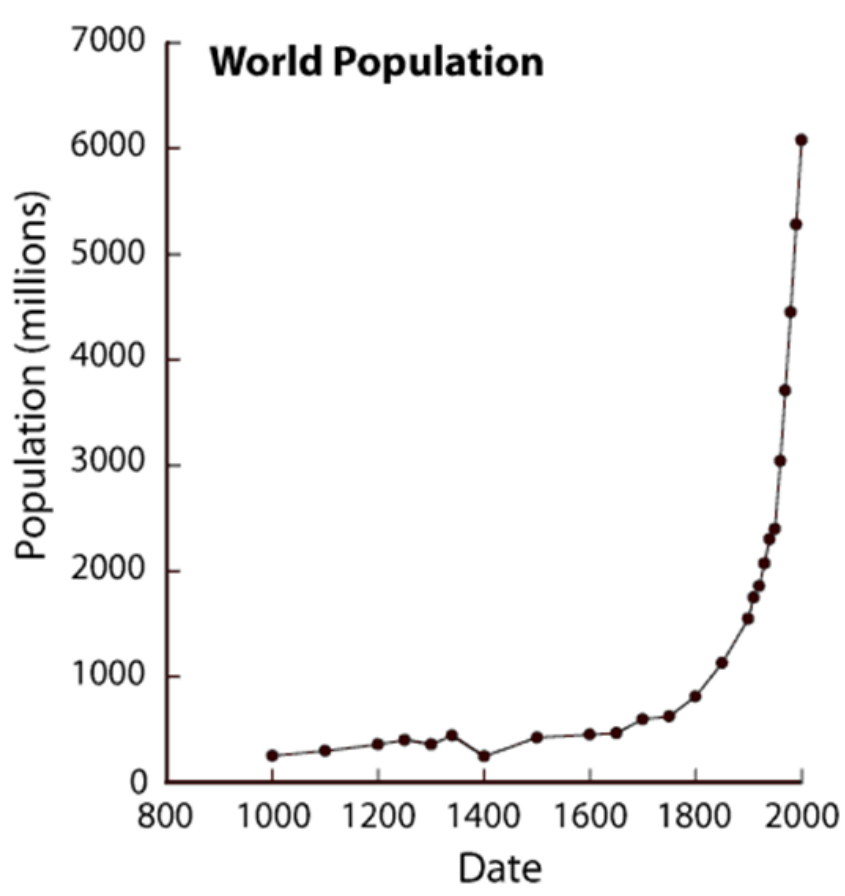

This diagram is a popular example of exponential growth, as is the case with the pandemic, as long as it can spread unhindered. However, there is no sign here of the flattening of the curve that people in the countries affected by C19 would like to see. With a constant earth surface, the average population density also increases according to this function. At the same time, urbanization is also being fuelled, so that today more than half of the people live in cities (Ritchie and Roser, 2018). This is also a consequence of fast and efficient transport systems (Knoflacher, 1993). From the C19's point of view, perfect "market conditions" for exponential growth. This again coincides perfectly with the ideas of the ideology of neoliberalism, driven by the corporate imperative for growth. Unfortunately, transport systems work both ways, a fact that has not yet made its way into the economic sciences, because they demand investment in even faster transport systems (Mondal, 2021). This changes economic structures because it leads to the destruction of small businesses and local jobs (Knoflacher, 1990). In the Corona crisis, one also recognizes the importance of certain self-sufficiency, not only for medical care and equipment. The relationship between $\mathrm{C} 19$ and the transport system is closer than one would think. 


\section{An analytical approach}

Traditional traffic planning uses the following formula to adapt roads to the demand of car traffic

$\mathrm{M}=\mathrm{D}^{*} \mathrm{~V}$.

M...number of cars per unit time (hour or day)

D....density (cars per $\mathrm{km}$ )

V...speed $(\mathrm{km} / \mathrm{h})$

The aim of this adjustment of transport and settlement structures is good "living conditions" for car drivers on the roads and sufficient parking spaces at the beginning and end of journeys, which are provided for by spatial and urban planners.

If the formula is applied to an area, such as a country, then M corresponds to the total vehicle kilometers per time unit, $\mathrm{D}$ is the number of cars and $\mathrm{V}$ is the average system speed. If one wants to calculate, for example, the exhaust gas pollution $\mathrm{P}$ from traffic, this can be done by a kilometer-related variable or factor $\mathrm{p}$.

$$
\mathrm{P}=\mathrm{p}^{*} \mathrm{M}=\mathrm{p}^{*} \mathrm{D}^{*} \mathrm{~V}
$$

Now, C19 is not interested in cars, but its newly conquered host organism, humans, is. The latter, however, does not only travel by car, but also on foot, by bicycle and by public transport, to name the most important. All four are welcome helpers to C19 in its spread.

For the modes of transport we introduce the index $\mathrm{i}$ and obtain the total load $\mathrm{P}$ by summing over all modes.

$$
\mathrm{P}=\sum \mathrm{p}^{*} \mathrm{Mi}=\sum \mathrm{p}^{*} \mathrm{Di}^{*} \mathrm{Vi}
$$

Since all variables are time-dependent and partially interdependent, we can differentiate this equation and analyze it further. In our case, $p$ stands for the specific infection load.

$$
\frac{d P}{d T}=\frac{d p}{d T} \cdot D \cdot V+p \cdot \frac{d D}{d T} \cdot V+p \cdot D \frac{d V}{d T} \text {. }
$$

Briefly, the first term describes the "technical protective measures" to influence the specific infection risk. Term 2 concerns the density control measures and term 3 the mean spatial dispersion velocity. It should also be noted that, as always in systems, there are interactions between the variables, 
which are also usually non-linear. To go into these in depth would go beyond the scope of this article.

In the formula, one only needs to insert the meaning of $p$ as specific infection load, which could be reduced to zero by technical measures, such as protective clothing, masks of different effects, hygiene measures such as disinfection, etc. and, in the hoped-for ideal case, at some point by protective vaccinations without side effects. Then everything would be as before C19. But since this is unlikely, the other two variables come into play: the reduction of density, fewer people per $\mathrm{m} 2$, especially in enclosed spaces but also in public street space, and reduction of speed for spatial mobility. The cancellation of mass events of any kind, reduces density by orders of magnitude. The number of spectators in a football stadium gathered on a maximum of 10 ha is often larger than the comparable population of a medium-sized city in Europe with an area of 600 ha or more. Crowds are ideal for contagion, in times of C19. The football match on 29 February between Villareal and Atalanta Bergamo, may have influenced the dramatic developments in Spain and Italy. Such agglomerations in a short space of time are, however, dependent on fast modes of transport. where there are again opportunities for spread on outward and return journeys.

\section{C19 highlights failures in many areas}

During the implementation of the measures, the failures of the past suddenly became visible. A small selection of them:

- In transport, because vast sums were invested in fast means of transport, which immediately became unusable with the emergency measures against C19 and revealed the pre-illnesses of an economy under profit- and/or credit-driven growth compulsion.

- In urban planning, where for four decades, against better and scientifically founded knowledge, too much space has been given to cars and too little space to people, citizens notice that the pavements are too narrow to keep the minimum distance of $1 \mathrm{~m}$ when meeting, while next to them $1.80 \mathrm{~m}$ wide cars are offered $3.5 \mathrm{~m}$ wide lanes that invite speeding.

- Architecture has also forgotten the experiences of hospital construction in the 19th century, when, in order to avoid infection, separate buildings were erected for the sick in self-sufficient buildings (pavilion style)(Wikipedia, 2021e), and not, out of short-sighted efficiency, 
huge structurally closed hospital complexes, which have to be artificially lit and ventilated and certainly form preferred biotopes for C19. A question also of hospital logistics, a branch of transport.

\section{The same formula, but the opposite goal}

The measures to avert the danger posed by C19 have exactly the opposite goal as the previous transport, urban and spatial planners: the former want to reduce $\mathrm{P}$ im ideally to zero with changes to $\mathrm{p}, \mathrm{D}$ and $\mathrm{V}$. The latter want to reduce " $\mathrm{p}$ " to zero through innovation and technology. Transport and urban policy focus on reducing " $\mathrm{p}$ " to zero through innovation and technology. But since this requires eliminating the laws of physics, it will probably remain an illusion, even if you replace the human in the car with a controller. C19 as a nanomachine (Falkowsky, 2019) is likely to be equipped with analogue IT anyway. The most effective measure against car addiction is to prevent the "docking" of the car to the home and all other places of human activity (Knoflacher, 2009). This measure has been shown to be most effective in combating viral infections. In the transport system, "maximum contagion" of the car virus is enforced by a law from the Third Reich (Wikimedia, 2021), which has been incorporated into all building codes.

\section{C19 and transport casualties Examples of thoughtless border crossings}

C19 is the result of the thoughtless intrusion of humans into nature, which was no longer respected in its intrinsic value, but devalued to the object of marketing. The zoonoses, which include the flu pandemics and also C19, are an indication of the loss of a sense of dangerous boundaries. The system- and life-sustaining dampening feedback, also called caution through experience, is lost through living away from nature. In C19, dampening feedback occurred relatively quickly and surprisingly, leading to correct action in most cases. However, even correct measures are only successful if they have a faster and stronger effect than the acceleration of the system's own dynamics. China has been quite successful so far, but it is difficult with political conglomerates like the EU or the USA, where it is no longer the health and wellbeing of the people that determine policy, but economic growth or military power. C19 has exposed the absurdity of these goals.

In transport, the ill-considered crossing of boundaries occurred over 100 years ago. with the ill-considered proliferation of the private car, which allows drivers to travel at speeds beyond their evolutionary experience. In 1861, 
people in England were still aware of the dangers of technical means of transport, such as the railways in 1861 Locomotive Acts, 1861) and, four years later, motor traffic in 1865 (Red Flag Acts, 1865) when the maximum speed was limited to $2 \mathrm{mph}$ in local areas and $4 \mathrm{mph}$ in open country. In 1869, the first fatality of this transport system, Mary Ward (Wikipedia, 2021f) ${ }^{2}$, is recorded. However, this did not stop automobile associations from gradually enforcing higher speeds from 1896 onwards and ushering in the motorization of society with the mass production of cars by Henry Ford (Wikipedia $2021 \mathrm{~g})^{3}$. The motorized society we still live in today transformed the world from one of people into a world for the car and car drivers. Without any scientific basis, guidelines were issued for the design and construction of roads, which not only increase the traffic problems to this day, but also the damage to the environment, economy and people.

The increasing number of deaths and injuries in this traffic system was only noticed by society after half a century in the 1950s, when associations were founded to increase road safety and road safety research began. This research, conducted by mechanical and civil engineers, focused primarily on the safety of car occupants and measures to mitigate the consequences of collisions. This corresponds to a sub-area of the first term in equation (4).

It was not until 1968, with the Vienna Convention on Road Traffic (Wikipedia, 2021h), that a global agreement on road traffic to increase road safety was reached for the first time. The effect of the car on the behavior of people and on the system of society, urban development, economy and environment only began to be perceived much later in the form of the obvious symptoms, although an exponential development of motorization had long since begun and powerful corporations in the car, oil, construction and finance industries determined the car business and provided people with the coveted car and a suitable environment.

\section{Evolutionary theory and evolutionary epistemology as tools}

Access to understanding the systemic effects on humans internally and society externally was hampered by the boundaries of the disciplines and each tried to solve the problems at the level of its perceived symptoms in a way that did not change the position of the car in space and in society. The fact that the car has its effects in very deep layers of our evolution(Riedl, 2019)

\footnotetext{
${ }^{2}$ Mary Ward (1827-1869) Ekim 2021 tarihinde https://en.wikip dia.org/wiki/Mary_Ward_adresinden erişildi. ${ }^{3}$ Henry Ford (1863-1947) Ekim 2021 tarihinde https://de.wikipedia.org/wiki/Henry_Ford adresinden erişildi.
} 
only began to be discovered at the beginning of the 1970s (Knoflacher, 1976). The breakthrough came a few years later when the homology of the behavior of bees (Frisch, 1965) and the behavior of the users of technical means of transport was recognized (Walther, 1975) and their cause was deciphered (Knoflacher, 1981) The car affects people and society like a virus affects the cell of its host organism, which switches its functions to favourable conditions for the development of the virus.

The difference between C19 and the car virus, however, is that C19 primarily alters the cells of the respiratory organs with sometimes fatal consequences for people, whereas the car alters the cells in the brain, which are responsible for energy calculation, in its sense. In this way, however, it also influences all recent evolutionary achievements in its way. People perceive the world in terms of the car (Knoflacher, 2009), concepts change and those killed become accident victims for economic progress. Corona-victims are perceived as symbols of threat and fear, while traffic fatalities are dismissed as collateral damage of a great technical development and progress. Effective measures are being put in place to contain the threat of C19, which also paralyses air and car traffic. The same efforts - but scientifically proven and practically demonstrated - are not accepted and the continued killing by the car traffic system is staunchly defended. The car in the brain makes unthinkable something that was normal for the entire history of mankind: a world without private cars.

\section{The consequences: Same effects are perceived and evaluated differently}

If one compares the number of pandemic deaths in recent decades, which ranges from 100,000 to four million, with the human casualties caused directly mechanically by car traffic and indirectly by its emissions, then car traffic "produces" 1.3 million accidental deaths every year (WHO, 2018). That is more than 3,600 traffic deaths per day as an average. In addition, more than twice that number of people die prematurely as a result of air pollution and particulate matter, and the deaths and illnesses caused by traffic noise are not attributed to traffic, but to the most common cause of death in today's society, cardiovascular disease. Moreover, traffic restricts people's active mobility and contributes to obesity. It would be a task for medical research in particular to address these "collateral statistics". But there is another important difference: C19 victims are predominantly pre-disabled and elderly people. The Autovirus, however, affects all age groups, especially the young and mostly healthy. 


\section{Conclusion: Can one learn from the experience with C19?}

One can, if one wants to. This has been proven with the measures taken to contain C19. It would be even easier to do so with the Autovirus, which is produced by people themselves. But not by changing the energy source from fossil to electric. For those killed and injured for life, it does not matter whether they are the victim of a car powered by fossil or electric energy. In order to implement the necessary measures for the preservation of human life and health in the transport sector, not only the hedonistic attitude of society, but also the power structures behind it would have to be changed. If one considers the sentence of the Federal President of Austria in his "calming speech" after two weeks of C19 measures "We must consider ourselves fortunate to live in a society in which every human life is worth the same" as the maxim of a civilised and cultured society, which it must be, then this does not correspond with reality, if one compares that of car traffic and the associated economy, which produces several million deaths and far more than ten times the number of seriously injured people every year, with the values of the pandemics. From Equation (4), the measures and also their priority can be derived:

1. car-free settlements and sanctions.

2. speed limits and effective control.

3. technical measures to minimise the risks of the remaining car traffic.

Car-free settlements are not only the result of the scientific impact analysis of the system of city and traffic, but also build on thousands of years of positive experiences of urban development.

Speed limits must not exceed the values for which we are evolutionarily equipped in our space-time perceptions and reactions.

Remaining car traffic are the journeys in the public interest, the economy and the disabled. Even under today's largely car-oriented structures, this proportion that cannot be handled by pedestrians, cycling and public transport is in the single-digit percentage range of weekday car trips. The consequences are not only fewer fatalities and injuries, but more active mobility in a healthier and more beautiful environment as people get back on their feet, like those recovering from C19.

C19 has made us aware of the major areas of the sick transport system. If society is capable of learning, it must get rid of them with C19 measures. Not 
only to protect people and the planet, but to still be able to face the much bigger threat of global warming in the future.

\section{Kaynakça/References}

Cliff A. D. (2021).Travel and Haggett Peter Time and infection. British Medical Bulletin 69(1):87-99 Ekim $2021 \quad$ tarihinde https://www.researchgate.net/publication/8482656_Time_travel_and_infection adresinden erişildi.

Falkowski, P. G.(2019). Life's Engines, How Microbes Made Earth Habitable, Princeton University Press.

Frisch, K.V. (1965). Tanzsprache und Orientierung der Bienen, Berlin-Heidelberg-New York: Springer-Verlag.

Knoflacher H. (1976). Einfluss der Fahrbahnlängsmarkierungen auf das Fahrverhalten der Fahrzeuglenker. Zeitschrift für Verkehrsrecht, Heft 5/1976.

Knoflacher H. (1985). Kann man Straßenbauten mit Zeiteinsparungen begründen. Internationales Verkehrswesen 38. Heft 6.

Knoflacher H. (1990). Einzelhandel, Geschwindigkeit des Verkehrssystems und Shoppingcenters. Salzburger Institut für Raumforschung, Mitteilungen und Berichte, 1-4/1990.

Knoflacher H. (2009). Virus Auto. Überreuther Verlag.

Knoflacher, H. (1981). Human Energy Expenditure in Different Modes: Implications for Town Planning. International Symposium on Surface Transportation System Performance. Washington DC.

Knoflacher, H. (1993). Verkehr - Stadtstruktur. Ökologische Qualitäten im Städtebau, Niedersächsisches Sozialministerium.

Kopits, E., Cropper, M. (2003).Traffic Fatalities and Economic Growth. World Bank Policy Research Working Paper 3030, April 2003.

Locomotive Acts (1961). Ekim 2021 tarihinde https://en.wikipedia.org/wiki/Locomotive_Acts adresinden erişildi.

Mondal, P. (2021). Relationship between Infrastructure and Economic Growth. Ekim 2021 tarihinde http://www.yourarticlelibrary.com/essay/relationship-betweeninfrastructure-and-economic-growth/33032 adresinden erişildi.

Red Flag Acts (1865). Ekim 2021 tarihinde https://de.wikipedia.org/wiki/Red_Flag_Act adresinden erişildi.

Riedl R. (1981). Biologie der Erkenntnis. Berlin Hamburg: Verlag Paul Paray.

Riedl R. (2019). Structures of Complexity. A morphology of Recognition and Explanation. Club of Vienna 2019.

Ritchie, H, and Roser, M. (2018). Urbanization. Publishes in https://ourworldindata.org/urbanization

Walther, K. (1975). Die fahrzeitäquivalente Reisezeit im öffentlichen Personennahverkehr. Verkehr und Technik (7), 271-275. 
WHO (2018). WHO Status Report on Road Safety 2018 Ekim 2021 tarihinde https://www.who.int/publications-detail/global-status-report-on-road-safety2018 adresinden erişildi.

Wikimedia (2021). Reichsgaragenordnung RGO. Reichsgesetzblatt Nr. 281939 Ekim 2021 https://commons.wikimedia.org/wiki/File:Deutsches_Reichsgesetzblatt_39T1_02 8_0219.jpg adresinden erişildi.

Wikipedia (2021a). $2002-2004$ SARS outbreak Ekim 2021 tarihinde https://en.wikipedia.org/wiki/2002\%E2\%80\%932004_SARS_outbreak adresinden erişildi.

Wikipedia (2021b). Historical GDP of China https://en.wikipedia.org/wiki/Historical_GDP_of_China adresinden erişildi.

Wikipedia (2021c). Verne Jules Around the world in Eighty Years Ekim 2021 tarihinde https://en.wikipedia.org/wiki/Around_the_World_in_Eighty_Days adresinden erişildi.

Wikipedia (2021d). Spanish flu Ekim 2021 tarihinde https:/en.wikipedia.org/wiki/Spanish_flu adresinden erişildi.

Wikipedia (2021e). Ekim 2021 tarihinde https://de.wikipedia.org/wiki/Pavillonstil adresinden erişildi.

Wikipedia (2021f). Ekim 2021 tarihinde https://en.wikipedia.org/wiki/Mary_Ward_ adresinden erişildi.

Wikipedia (2021g). Ekim 2021 tarihinde https://de.wikipedia.org/wiki/Henry_Ford adresinden erişildi

Wikipedia (2021h). Vienna Convention on Road Traffic (1968) Ekim 2021 tarihinde https://en.wikipedia.org/wiki/Vienna_Convention_on_Road_Traffic adresinden erişildi.

Zahran, Y. (2021). What number was the Earth population in the year 1001?. Ekim 2021 tarihinde https://www.quora.com/What-number-was-the-Earthpopulation-in-the-year-1001 adresinden erişildi. 